\title{
HRASLS wt Allele
}

National Cancer Institute

\section{Source}

National Cancer Institute. HRASLS wt Allele. NCI Thesaurus. Code C153057.

Human HRASLS wild-type allele is located in the vicinity of 3q29 and is approximately 60 $\mathrm{kb}$ in length. This allele, which encodes phospholipid-metabolizing enzyme A-C1 protein, is involved in lipid metabolism. 